\title{
The Influence of Multimodal Teaching on Cultivating Multiliteracies
}

\author{
Yue Yuanyuan \\ Qu Fu Normal University, Shandong, China
}

\begin{abstract}
With the development of economic globalization and technological advances of communication, modern means of communication has already transformed from traditional letter writing and meeting face-to-face to multimodality which is the composition of two or more than two means of representation and communication. The traditional literacy based on reading and writing has been unable to meet the needs of learners in multimodal age. In such a social context, cultivating students' multiliteracies has become a tendency in language education. The multimodal discourse analysis theory within Halliday's systemic functional grammar provides a theory framework for multiliteracies. Scholars at home and abroad have done some studies on theory frameworks of multimodality. Comparatively speaking, not much attention has been paid to study the impact of multimodal teaching on multiliteracy training in college English class. Based on previous studies, the paper explores the impact of multimodality in cultivating college students’ multiliteracies.
\end{abstract}

Keywords: college English, multiliteracies, multimodal teaching

\section{Introduction}

At present, as human beings have marched into a new age, economic globalization, cultural diversification, and informationization in social life are developing rapidly, which increasingly influence and change people's daily lives. New technologies have been playing significant roles in modern society. With the proliferation of those new technologies, the means of human communication are getting rich and colorful. The ways of expression and transmission of meanings keep changing as well. Today's technological advances of communication have made it very easy for people to communicate with each other. With the help of diverse effective tools, communication can be conducted without the limitation of time and space. Our modern means of communication have already transformed from traditional letter writing and meeting face-to-face to smart phone, video software, and instant messenger. In other words, people no longer use certain simple mode or media to communicate. The traditional literacy based on reading and writing has been unable to meet the needs of learners in multimodal age. In such social context, the connotation of literacy has undergone a significant change. The way of getting knowledge transformed from the traditional way that is focused on language to multiliteracy which is composed of semiotic systems. The change has a great impact on our foreign language teaching and learning. How to cultivate students' multiliteracies through multimodality and help them adapt to the economic globalization, cultural diversity, and communication diversification became an urgent task for foreign language education reform.

Yue Yuanyuan, lecturer, Foreign Languages Research and Teaching Department, Qu Fu Normal University. 
The concept of multiliteracies was raised by the New London Group which was composed of 10 academics. They came together in 1996 concerned about how literacy pedagogy might address the rapid change in literacy due to globalization, technology, and increasing cultural and social diversity. The result of the academic discussion was a paper named Pedagogy of Multiliteracies: Designing Social Futures (New London Group, 1996), which is a landmark for the studies on multiliteracies. From then on, linguists and educators around the world have been doing extensive research. Abroad, the main representatives are Kress and Van Leeuwen, Thwaites, Williamson, Spiliotopoubs, Knight and Corrigan, etc.. It is Kress and Van Leeuwen who first brought about the multiliteracies. They studied the theory on the basis of Halliday's socio-semiotic theory. They first studied the visual aspect of multiliteracies. They have expanded Halliday's socio-semiotic theory to visual grammar and think images can express meaning as language does. In Spiliotopoubs's (2005) opinion, multiliteracies mean people can understand a various modes of discourses through a variety of information transmission and information networks. In China, many scholars have already showed their great attention to multiliteracies study. Among the domestic scholars, Professor Hu Zhuanglin (2007) first started the relative studies. He pointed out that multiliteracies cover both cultural literacy and technological literacy. And participants not only can read text information, but also have the ability to explain the symbols and images, to use the multimedia technology and other tools, such as the Internet.

\section{Multimodality}

It is generally believed that the traditional view of literacy does not meet the needs of modern communication in today's globalized society any more. Being able to read and write is no longer qualified in today's technology-dominated world. Therefore, how to cultivate multiliteracies ability becomes the key element in nowadays language teaching. Here we are, multimodality jumped into our horizon.

Multimodality had emerged out of scholarship published in the last decade of 20th century. To start with, we had better figure out the other two terms: media and modality. They discussed thoroughly on the relation between modes and media in this way. A whole other set of skills is involved here: technical skill, skills of the hand and the eyes, skills related not to semiotic modes, but to semiotic media. We use the term "medium" here in the sense of medium of execution. Multimodality is the composition of two or more than two means of representation and communication, such as image, posture, speech, gesture, music, writing, or new configuration of these elements. Multimodality has been widely discussed by the scholars in the field of linguistics and semiotics at home and abroad in recent years. Van Leeuwen (2005) defined multimodality as the combination of different semiotic modalities—-for instance, language and music — in a communicative artifact or event. According to Baldry and Thibault (2006), multimodality means the various ways in which a number of distinct semiotic resource systems are both co-deployed and co-contextualised in the making of a text-specific meaning. In China, one of the most constructive researches on multimodality is made by Zhang Delu. His theoretical framework for multimodal discourse analysis (MDA) was based on Halliday's systemic functional linguistics. Li Zhanzi (2003) introduced Kress' theory and offered other comprehensive explanations of MDA. Gu Yueguo formed his own analysis framework based on activity theory. The other representatives in this field also include Hu Zhuanglin, Zhu Yongsheng, Zeng Lei, and Ye Qichang, etc.. Comparing to researches abroad, domestic studies of MDA are relatively fallen behind. Meanwhile, those scholars, like Gu Yueguo, Zhang Delu, Zhu Yongsheng, and Wei Hongqin, have done many theoretical and empirical researches on multiliteracies. 
As to the traditional classroom teaching, teachers occupy the dominant position in class. Almost all of the language points, grammars, textbook understanding, even exercises are conducted through teachers oral presentation and blackboard-writing. Students seldom get involved in the process. Gradually, the "duck-stuffing" type of teaching makes students lose their motivation to learn, not to mention get fun from learning. On the other hand, the traditional monomodal instruction increased the risk of teachers' burnout. And teachers are eager to jump out of the awkward teaching environment.

The theory of multimodality meanwhile brings about significant change in English teaching and learning. With the multimedia equipment usage in classroom, multimodal instructions dominate today's language teaching and leaning realm. Multimodal pedagogy gives a huge advantage over the traditional classroom teaching. Multimodal English teaching, combining such modals as words, sound, pictures, color, and typography and involving different sensory modalities, such as visual and auditory senses, is better received by students and is more effective in terms of the development of students' language literacy, communicative competence, and media literacy than the traditional English teaching. Multimodal teaching plays a significant role in stimulating interest and enthusiasm in learning foreign language and culture, and improving academic performance. In order to figure out the answers to the questions above, both qualitative and quantitative studies are conducted in this paper. The involvement of multimodality in class is mainly through the application of multimodal PowerPoint (PPT). Besides, teachers' classroom multimodality discourse also plays a role.

\section{Research Design}

This paper aims to explore how multimodal instruction works in cultivating students' multiliteracies ability. Therefore, the paper can provide some meaningful references to college English teaching reform. Universities should positively change the traditional teaching mode, methods, and teaching content, attaching great importance to cultivating multiliteracies ability.

The study mainly involves two questions: (1) To evaluate the cognition of the multiliteracies ability among non-English majors; and (2) To testify the positive impact of the multimodal teaching on college students' multiliteracies training and confirm the effectiveness of multimodality instruction as well.

The study will be conducted through questionnaire and class observation. There are two questionnaires. All the students involved in the two questionnaires are freshmen of non-English majors. One of the questionnaires is to investigate college students' awareness and ability of multiliteracies. The other is designed to inquire students' recognition and attitude to multimodal teaching methods, like the application of the PPT courseware and teachers' multimodal discourse analysis.

In order to obtain the first-hand data, the research will be conducted among real college non-English major students. The author carried out 10 weeks of classroom observation. Two parallel classes involved in the process. One is the experimental class (EC). Meanwhile, the other class is the control class (CC). The age of these non-English major participants generally ranged from 19-20 years old. They have undergone the English level-based test when they just entered college. The two classes are both normal classes. The overall English level of those participants is basically the same. Through the author's usual contact and classroom observation, the participants revealed no obvious differences in learning motivation, interest, and learning habits. And individual differences are too little to affect the validity of test data. In the control class, traditional teaching method is widely used which is mainly through teacher's presentation and explanation. Whereas, in the experimental class, multimodal teaching goes through three class links, including the introduction to text, 
explanation to language points, and exercises. Outside the classroom, the students in EC are strongly recommended to find the video and audio references, or pictures via Internet and other multimedia. At the end of the experiment, students both in the CC and EC will take a test, the result will be used to evaluate students' academic performance and figure out the impact of multimodal teaching in developing students' traditional reading and writing literacy, video-audio literacy, and multimedia-based literacy.

\section{Conclusion}

Through the above study, there are some conclusions and suggestions implied. First, multimodal teaching instruction can stimulate students' learning enthusiasm and strengthen their learning initiative. Multimodal teaching has a positive impact on cultivating college students' multiliteracies, especially their video-audio literacy, social communicative ability, and multimedia-based literacy. Second, the role of a teacher in traditional English class should transform from the dominant to the participant, which means that teachers do not play the main characters in nowadays classes. What the teachers should do is to create an environment with the help of multimodalities for the students to study by themselves. In multimodal classrooms, the close cooperation between teachers and students is the same critical. Teachers should intentionally guide students to get access to multimodalities. For instance, the teacher can arrange students' homework after class to make PPT courseware in which some multimodal elements should be applied, like sounds, images, cartoons, charts, and so on. In the process of finishing their homework, students can achieve a better understanding about various semiotics. Third, multiliteracy training cannot be done without certain material guarantee. Teachers should select and integrate different modalities in an effective and efficient way, therefore students can utilize varieties of multimodal resources to create and convey ideas. Teachers should make use of various kinds of teaching aids to make the multimodal surroundings in classes, like texts, sounds, videos, PPT coursewares, and Internet. Cultivating students' multiliteracies needs not only the hard works of both teachers and students, but the encouragement and support from college administrators. They should provide college English teaching process with necessary multimodal facilities and updates equipment. Some teaching resources should be assigned to teachers use and easily accessed by students. Last but not least, the assessment of multiliteracy teaching and students' performance is of great importance. Especially, the students' academic performances cannot be merely judged by their final written examination. Their performance in class, such as presentation of PPT or their role play, should be a part of their final score, which can well encourage students to emphasize and promote their multiliteracies.

\section{References}

Baldry, A., \& Thibault, P. J. (2006). Multimodal transcription and text analysis. London: Equinox.

Cope, B., \& Kalantzis, M. (Eds.). (2000). Multiliteracies: Literacy learning and the design of social futures. London: Routledge. Gu, Y. G. (2007). On multimedia learning and multimodal learning. Computer-assisted Foreign Language Education, $29(2), 3-12$. (in Chinese)

Halliday, M. A. K. (2000). An introduction to functional grammar. Beijing: Foreign Language Teaching and Research Press. Hu, Z. L. (2007). Multimodalization in social semiotics. Language Teaching and Linguistic Studies, 29(1), 1-10. (in Chinese) Hu, Z. L. (2007). PowerPoint-Tool text genre style. Foreign Language Education, 28(4), 1-5. (in Chinese)

Kress, G. (2000). Multimodality. In B. Cope \& M. Kalantzis (Eds.), Multiliteracies: Literacy learning and the design of social futures. London: Routledge.

Kress, G. (June, 2000). Multimodality: Challenges to think about language. TESOL Quarterly.

Kress, G. (2003). Literacy in the new media age. London: Routledge. 
Kress, G. R., \& Van Leeuwen, T. (1996). Reading images: The grammar of visual design. New York, N.Y.: Routledge.

Kress, G., \& Van Leeuwen, T. (2001). Multimodal discourse: The modes and media of contemporary communication. London: Arnold.

Li, Z. Z. (2003). Social semiotic approach to multimodal discourse. Foreign Languages Research, 20(5), 1-8. (in Chinese)

New London Group. (1996). Pedagogy of multiliteracies: Designing social futures. Harvard Educational Review, 66(1), 60-93.

Norris, S. (2004). Analyzing multimodal interaction: A methodological framework. London: Routledge.

Royce, T. D. (2007). Multimodal communication competence in second language context. In T. D. Royce \& W. L. Bowcher (Eds.), New directions in the analysis of multimodal discourse. Mahwah, N.J.: Lawrence Erlbaum Associates.

Spiliotopoulous, V. (2005). Developing multiliteracy in adult ESL learners using online forums. International Journal of the Humanities, (1).

Thwaits, T. (1999). Multiliteracies: A new direction for arts education. Retrieved from http://swin.edu.au/aare/99pap/thw995 28.htm

Van Leeuwen, T. (2005). Introducing social semiotics. London: Routledge.

Wei, Q. H. (2009). A study on multimodality and college students multiliteracies. Computer-Assisted Foreign Language Education, 31(2), 28-32. (in Chinese)

Williamson, B. (2005). What are multimodality, multisemiotics and multiliteracies? - A brief guide to some jargon. Retrieved from http: //www.futurelab.org.uk/viewpoint/art49.htm

Zhang, D. L. (2009). On a synthetic theoretical framework for multimodal discourse analysis. Foreign Languages in China, 6(1), 24-30. (in Chinese)

Zhang, D. L., \& Wang, L. (2010). The synergy of different modes in multimodal discourse and their realization in foreign language teaching. Foreign Language Research, 33(2), 97-102. (in Chinese)

Zhu, Y. S. (2007). Theory and methodology of multimodal discourse analysis. Foreign Language Research, 30(5), 82-86. (in Chinese) 